\title{
SEDIMENTOLOGY, DEPOSITIONAL ENVIRONMENTS AND BASIN EVOLUTION OF COAL AND OIL SHALE-BEARING SEDIMENTS IN THE DELBI-MOYE BASIN, SOUTHWESTERN ETHIOPIA
}

\author{
Wolela Ahmed \\ Department of Petroleum Operations, Ministry of Mines, PO Box 486 \\ Addis Ababa, Ethiopia. E-mail: Wolela_am@Yahoo.com
}

\begin{abstract}
The Inter-Trappean coal and oil shale-bearing sedimentation in the Delbi-Moye Basin took place in tectonically controlled grabens and half-grabens formed by extensional fault systems and accompanied by passive subsidence. The sedimentation history of the basin is related to the tectonic events that affected East Africa. The Delbi-Moye Basin consists of two sedimentary units (upper and lower sedimentary units). The upper and lower sedimentary units attain maximum thicknesses of 40 and 278 meters respectively. The upper sedimentary unit is characterized by one sedimentary cycle. The lower sedimentary unit is characterized by three sedimentary cycles, and defined by five sedimentary facies (coal-bearing sediments, upper oil shale facies, upper mudstone facies, lower oil shale facies and lower mudstone facies). The coarser clastic sediments were deposited at the basin margins, whereas the concentration of fine-grained clastic sediments and organogenic deposits (oil shale and sapropelic coal) was high at the depocenter of the basin. The sedimentation is defined by alluvial fan, fluviatile, off shore lacustrine, shoreline lacustrine and paludal and/or swampy depositonal environments.
\end{abstract}

Key words/phrases: Alluvial fan, Delbi-Moye, fluviatile, lacustrine, sedimentology/depositional environments

\section{INTRODUCTION}

The Delbi-Moye Basin is situated between $7^{\circ}$ $21^{\prime} 49^{\prime \prime}-7^{\circ} 24^{\prime} 31^{\prime \prime} \mathrm{N}$ and $36^{\circ} 48^{\prime} 21^{\prime \prime}-36^{\circ} 52^{\prime} 54^{\prime \prime} \mathrm{E}$ latitude and longitude, respectively (Figures 1 and 2). Delbi is a small village $390 \mathrm{kms}$ southwest of Addis Ababa, and $50 \mathrm{kms}$ south of Jimma town. The area can be reached by asphalt surfaced road from Addis Ababa to Jimma, and the remaining 50 kms Jimma to Delbi by all-weather gravel surfaced road. Delbi-Moye Basin is found on the Southwestern Plateau of Ethiopia between 1660 and 2240 meters above sea level.

The north-south and east-west trending perennial and intermittent streams are controlled by the master drainage system of Gojeb River, which enters the Omo River. Morphologically, the basin consists of basaltic ridges, north-south aligned trachytic hills, deeply dissected basaltfloored stream channels and associated lowlands. Vegetation is diverse ranging from savanna grassland to tropical rainforest. The basin receives rainfall twice a year from mid-June to end of August and from November to February.

\section{PREVIOUS WORK}

Heeman et al. (1984) conducted a reconnaissance geological survey, logged the stream channels of Legamse and reported analyses results of coal samples. Minye Betru et al. (1987) carried out a regional geological survey $(1: 50,000)$ and logged sections in the stream channels of Legamse, Gonfa and Keso and discovered the Didibo, Yeba, Ramete and Hora coal-bearing sediments. They also reported analytical results on coal samples. Assefa Aklilu et al. (1987) carried out a semi-detailed geological survey $(1: 25,000)$. Sections were logged in the stream channels of Legamse, Tingura, Didbo, Yeba, Hora and Ramte streams and their tributaries. Analytical results are reported on numerous samples for their proximate analysis and calorific values. Minye Betru et al. (1988) produced a detailed geological map $(1: 10,000)$ of Delbi area, and logged representative sections at Legamse, Okoshe, Gonfa, and Merchancha Streams. Bae et al. (1989) made an improved version of the geological map of the Delbi-Moye Basin. East-west and north-south drilling profiles were proposed, and a total of 25 boreholes were sunk within 25 square kilometres. Bae et al. (1991); 
Wolela Ahmed (1991 a\&b); Wolela Ahmed (1992 a\&b); Tessfaye Lema et al. (1992); Getahun Belay et al. (1993); Wolela Ahmed (1995); Tessfaye Lema and Minye Betru (1995) produced geological reports and publications on the surface and subsurface geology, geochemical characteristics and reserve estimation of the coal and oil shale deposits of Delbi-Moye Basin. AMOCO (1988) Shigute Geleta (1988) and Crude Oil Institute of
Korea (1988) carried out palynological studies on the Delbi-Moye coal and oil shale-bearing sediments. Only scanty information is available regarding the sedimentology/depositional environments and basin evolution of the Delbi-Moye Basin. This paper presents a detailed account of the sedimentology, depositional environments and basin evolution of the Delbi-Moye Basin.

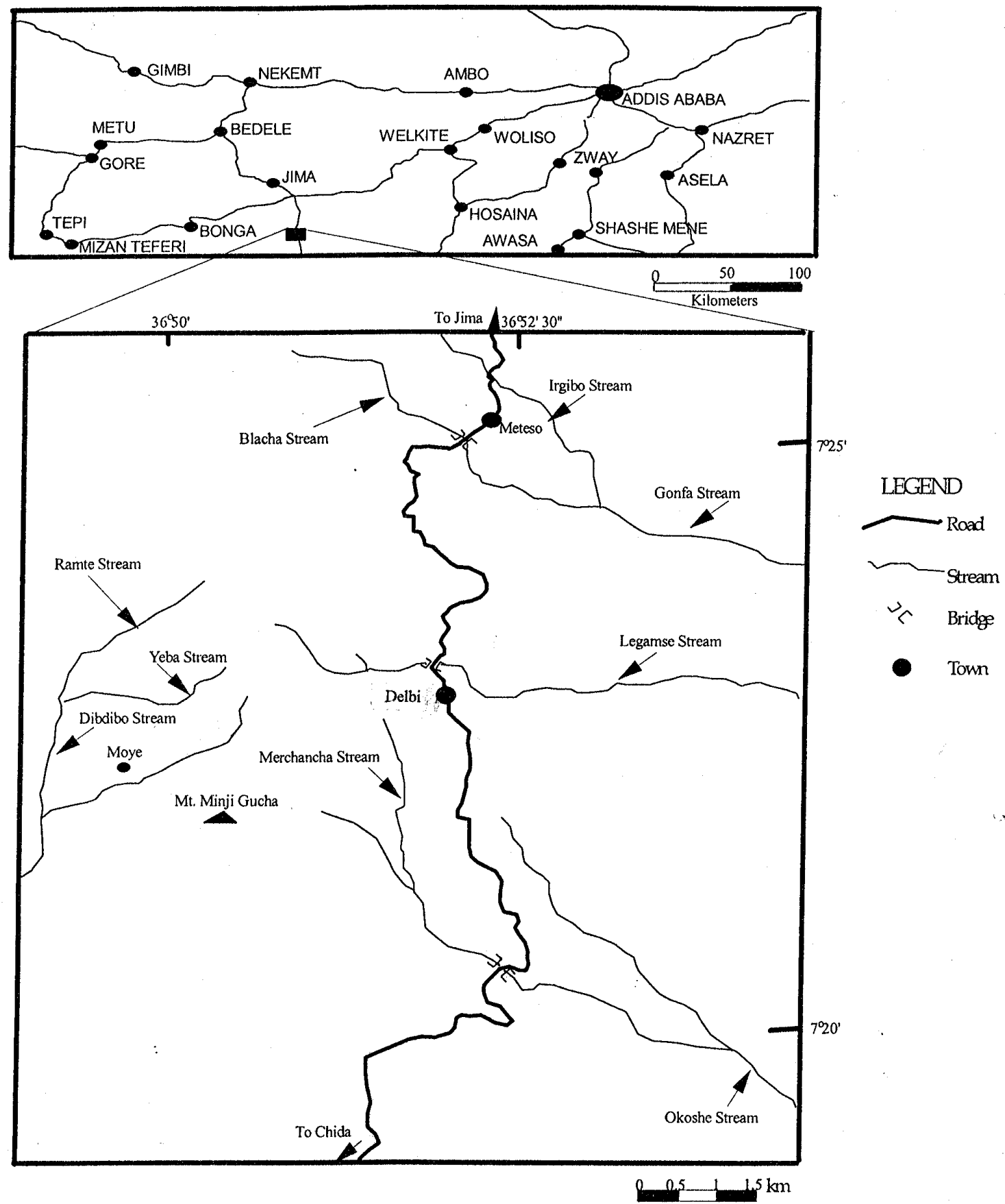

Fig. 1. Location map of studied area. 


\section{GEOLOGY OF THE STUDIED AREA}

The geology of the Delbi-Moye Basin is described in relation to the regional Precambrian orogenic belt and the younger rift tectonics. Structural studies conducted at a regional scale (Wolela Ahmed, 1991a; Bae et al., 1989; Minye Betru et al., 1988) indicate sub-parallelism between the Precambrian orogenic belts and younger rift system. The basin underwent various degrees of tectonic disturbance. The structural evolution of the region is in accordance with the NNW-SSE, eastwest extensional tectonics and the Main Ethiopian Rift system, which accounted for the structural complexities of the basin (Bae et al., 1989; Wolela Ahmed, 1991a). These rift systems were accompanied by voluminous lava flows.

The Delbi-Moye Basin consists of six major rock units: (i) lower basalt (basalt-I), (ii) lower sedimentary unit (sediment-I), (iii) middle basalt (basalt-II), (iv) upper sedimentary unit (sedimentII), (v) upper basalt (basalt-III) and (vi) intermediate-acidic volcanics (see Figs 3, 4, 5, 6, 7 and 8). Unconformities are traceable: (i) between the lower basalt and the lower sedimentary formation; (ii) between the lower sedimentary formation and the middle basalt; and (iii) between the middle basalt and upper sedimentary formation. Unconformities are also observed at different levels within the sedimentary units.

The lower basalt is the oldest exposed rock unit and represents a pre-rift volcanic series in the basin. Unconformity surfaces in the form of paleosols were encountered at different levels indicating different episodes of eruption. The unit is exposed in the deeper valley, and forms the substratum of the lower sedimentary unit. The lower basalt is porphyritic with phenocrysts of plagioclase and pyroxene phenocrysts set within fine groundmass, and is vesicular to amygdaloidal. The vesicles are infilled by calcite, silica and hematite. Chloritization, silicification and limonitization have resulted from hydrothermal effects. The unit is cut by east-west and northsouth trending fractures, which are filled by calcite and quartz veinlets. Core studies also confirmed the presence of parallel, oblique and perpendicular fracture to the core axis.
The lower basalt is probably of EoceneOligocene age and may be grouped under the Ashanghe basalt series (Kazmin, 1972; Mengesha Tefera et al., 1996). The Ashanghe basalt series in the region consists of alkaline olivine basalts and tuff, and rare rhyolite products accompanied by doleritic sills and gabbro-diabase intrusives (Kazmin, 1972; 1975). The lower basalt has been dated to be 31Ma (Zanettin and Justin-Visentin, 1974).

The middle and upper basalt units are petrographically dominated by plagioclase, pyroxene and olivine phenocrysts. The middle and the upper basalt units are grouped under OligoMiocene Tarmaber Guassa Formation (Mengesha Tefera et al., 1996).

The intermediate-acidic rocks consist of trachyte and rhyolite lavas and domes and minor amounts of andesite. The unit unconformably overlies the upper basalt, and forms trachyte and rhyolite domes and plugs that are aligned along the major north-south oriented structures of the region. Analytical X-ray fluorescence results on representative samples are reported in Table 1. Ternary plots of the volcanic rocks fall predominantly in the tholeiitic basalt with minor amounts of calc-alkaline basalt using magnesium oxide, aluminium oxide and iron oxides ternary end members.

Two episodes of inter-volcanic sedimentation occurred within the volcanic flows. The lower sedimentary unit (sediment-I) was deposited on a basaltic substratum of the Ashanghe basalt series, and attains a maximum thickness of 278 meters. The upper sedimentary unit (sediment-II) ranges in thickness from $0-40 \mathrm{~m}$. The lower and upper sedimentary units in the Delbi-Moye Basin are composed of mainly $30 \%$ coarser clasts and $70 \%$ by finer clasts (by volume). The lower sedimentary unit separates the lower basalt from the middle basalt, whereas the upper sedimentary formation separates the middle basalt from the upper basalt (see Figures 3\&4). Offshoot from intermediateacidic volcanic intrusions in the coal and oil shalebearing sediments produced small gas-pockets. The lithological distribution and chronolithostratigraphic section are shown in Figures 2 and 4, respectively. 


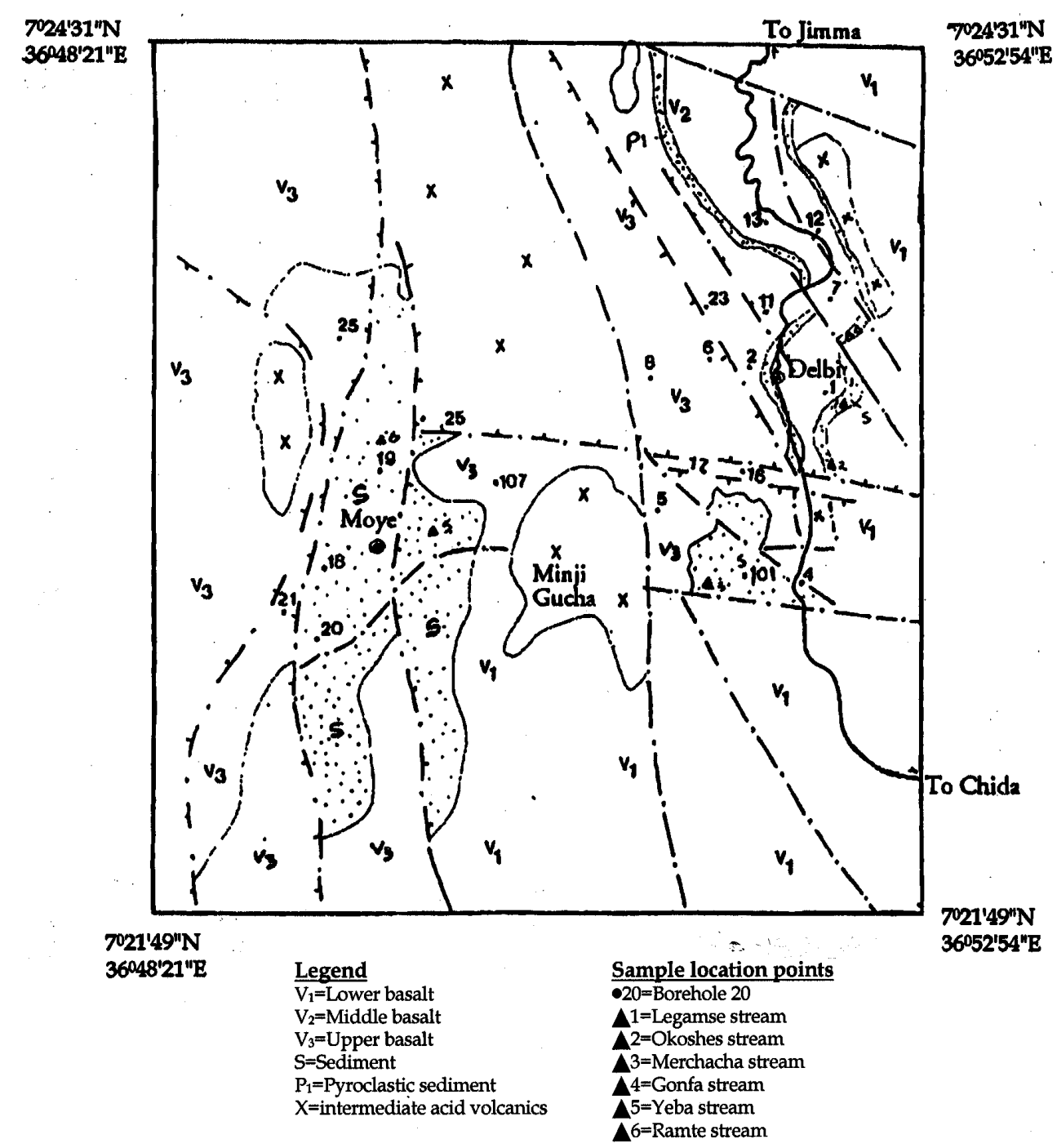

Fig. 2. Sample location and geological map of the Delbi-Moye Basin (modified after Bae et al., 1991).

Table 1. Analytical XRF results of representative volcanic rocks in the Delbi-Moye Basin.

\begin{tabular}{lccrrrrrrrrrrr}
\hline Sample type & $\mathrm{SiO}_{2}$ & $\mathrm{Al}_{2} \mathrm{O}_{3}$ & $\mathrm{Fe}_{2} \mathrm{O}_{3}$ & $\mathrm{FeO}$ & $\mathrm{MgO}$ & $\mathrm{CaO}$ & $\mathrm{MnO}$ & $\mathrm{Na}_{2} \mathrm{O}$ & $\mathrm{K}_{2} \mathrm{O}$ & $\mathrm{TiO}_{2}$ & $\mathrm{P}_{2} \mathrm{O}_{5}$ & $\mathrm{H}_{2} \mathrm{O}$ & $\mathrm{LOI}$ \\
\hline Lower basalt & 44.48 & 14.46 & 4.83 & 5.95 & 3.40 & 12.80 & 0.01 & 2.4 & 2.30 & 2.0 & 0.41 & 0.10 & 1.42 \\
Middle basalt & 47.80 & 14.60 & 5.56 & 4.23 & 4.01 & 10.20 & 0.01 & 3.2 & 2.33 & 1.2 & 0.45 & 0.80 & 4.00 \\
Upper basalt & 50.60 & 13.40 & 7.14 & 4.97 & 3.23 & 8.57 & 0.01 & 2.4 & 1.60 & 2.0 & 0.45 & 0.20 & 5.00 \\
Andesite & 62.23 & 13.75 & 8.40 & 1.28 & 0.86 & 1.36 & 0.02 & 3.5 & 4.20 & 0.6 & 0.10 & 0.10 & 4.00 \\
Trachyte & 60.17 & 14.63 & 4.10 & 1.06 & 0.09 & 1.50 & 0.02 & 3.2 & 2.00 & 0.3 & 0.18 & 0.15 & 4.25 \\
\hline
\end{tabular}

The sediments were deposited within NNW-SSE trending graben and half-grabens. During EoceneEarly Oligocene, a shallow protorift was formed in the South-western Ethiopian Plateau (Seife Michael Berhe et al., 1987). This rift basin is closely related to the extensional tectonics during the development of the Ashanghe Rift (Seife Michael Berhe, 1987). The NNW-SSE trending fault system is possibly correlable to the Pibor Rift system, in the
Melut Basin of Sudan. Paleogene sedimentation is recorded in the Melut Basin (Ebinger et al., 1993; Ebinger and Ibrahim, 1994). Palynology studies confirmed that the sedimentation in the DelbiMoye Basin was initiated in Eocene or Oligocene time (see Table 2).

After volcanism and sedimentation the NNW-SSE trending fault system rejuvenated and dissected the whole sedimentary succession and volcanic 
rocks. The displacement in the basin ranges from 50-200 m. The structural pattern with major displacements is shown in Figures 3, 4 and 8. After the rejuvenation of the NNW-SSE fault system, the volcanic and the sedimentary rocks were affected by the youngest ENE-WSW trending fault system in the Late Tertiary.

\begin{tabular}{|c|c|c|c|c|c|c|c|c|}
\hline Age & Unit & $\begin{array}{l}\begin{array}{l}\text { Thickness } \\
\text { (m) }\end{array} \\
\end{array}$ & Llthology & Major descriptive features & Depositional & environment & Cycle & $\begin{array}{c}\text { Tydrocarbon } \\
\text { play }\end{array}$ \\
\hline & & & & & Continental & environment & & \\
\hline & & & Moye Delbl & & 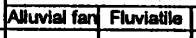 & \begin{tabular}{|l|l|}
$L$ Lecustring Swampy \\
\end{tabular} & & \\
\hline$?$ & $\begin{array}{c}\text { Intermidato-acidic } \\
\text { volcanlc }\end{array}$ & $0-100$ & $\begin{array}{lll}x & & x \\
& x^{2} \\
\end{array}$ & Rhyolite, trachyte and rare andeslte & & & & Soed (?) \\
\hline$?$ & Upper basall & $0-100$ & 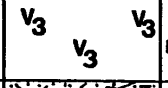 & $\begin{array}{c}\text { Plaglodase porphyritic besalt seperated by } \\
\text { paloosols and tuffs } \\
\end{array}$ & & & & Seal (?) \\
\hline & $\begin{array}{c}\text { Uppor sodimentary } \\
\text { formation }\end{array}$ & 0.20 & 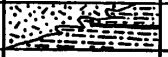 & $\begin{array}{c}\text { Pyroclastic sediments and carbonacoous } \\
\text { clay }\end{array}$ & & & & \\
\hline $\begin{array}{l}\text { U. Miocene- } \\
\text { Pliestiocene }\end{array}$ & Middle basalt & $0-80$ & $\begin{array}{|lll|}v_{2} & & v_{2} \\
& v_{2} & \\
\end{array}$ & \begin{tabular}{|l|}
$\begin{array}{c}\text { Pyroxeno-plagloclase baselt with abundant } \\
\text { sllica, zoolite end calclite infilling. }\end{array}$ \\
\end{tabular} & & & & $\operatorname{sen}(?)$ \\
\hline & & & 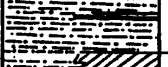 & Coostbearing codments & & & Throe & Source \\
\hline & & & 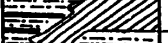 & Upper oil shale facies & & & Two & Sourcea/sead \\
\hline Ollgocene-Mlocene & Lower sodimentary & 0.278 & 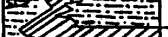 & Upper mudstone faclos & & & & Sourcatresenvolr \\
\hline & & & II & Lower oll strale facles & & & & Source/soed \\
\hline & & & 19: & I mudstone factes & & & $0 n$ & Roservotr \\
\hline $\begin{array}{l}\text { Paleocene-Ollgoceno- } \\
\text { Milocene }\end{array}$ & Lower basalt & & $v_{1} v_{1} v_{1}$ & 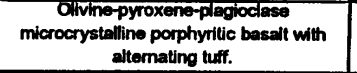 & & & & \\
\hline
\end{tabular}

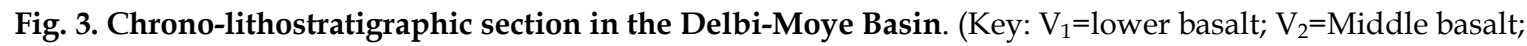
$\mathrm{V}_{3}=$ Upper basalt; $\mathrm{X}=$ Intermidate acidic rocks.)
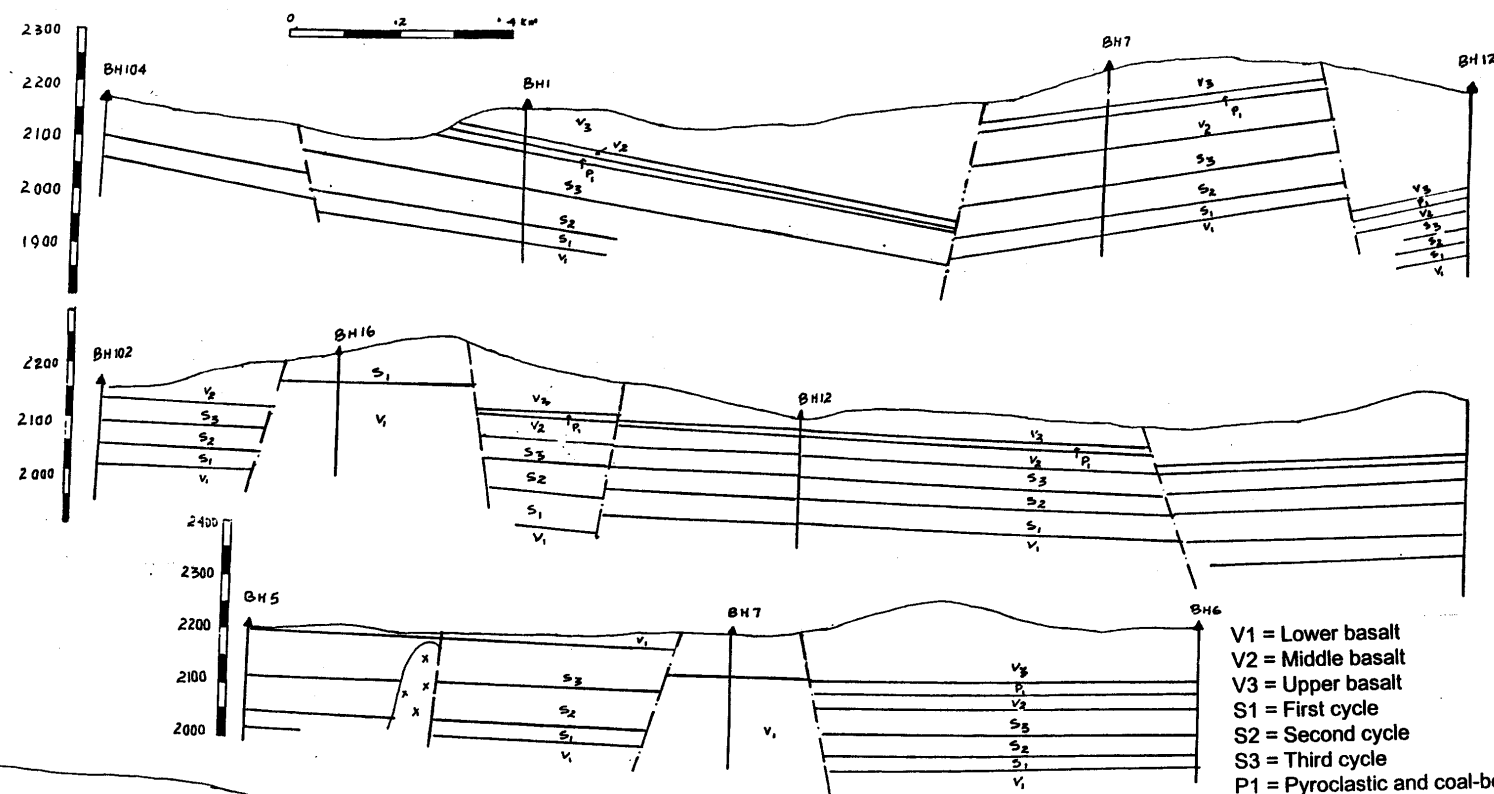
$V 1=$ Lower basalt $\mathrm{V} 2=$ Middle basalt V $3=$ Upper basalt S1 $=$ First cycle $\mathrm{S} 2=$ Second cycle S2 $=$ Third cycle $\mathrm{S} 3=$ Third cycle
$\mathrm{P} 1=$ Pyroclastic and coal-bearin $\mathrm{X}=$ Intermidate-acidic volcanic

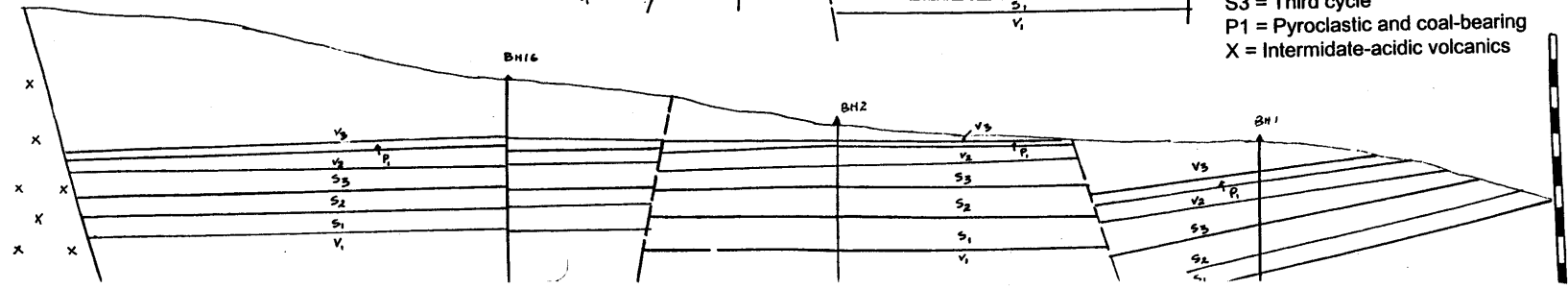

Fig. 4. Structural (tectonic) interpretation showing fault pattern and displacement based on borehole data (simplified after Bae et al., 1991). 


\section{SEDIMENTOLOGY}

Surface and subsurface geological data shows that the Delbi-Moye Basin consists of two sedimentary units: (i) the lower sedimentary unit (sediment-I) and (ii) the upper sedimentary unit (sediment-II). The upper and lower sedimentary units are defined by one and three sedimentary cycles respectively. Most of the coal and oil shale-bearing sediments are found in the lower sedimentary formation. The sediments in general dip up to $30^{\circ}$ towards west. Facies variation and inter-fingering of facies is well exhibited in the sedimentation.

\section{Lower sedimentary unit}

The lower sedimentary unit in the Delbi-Moye Basin consists mainly of terrigenous clastics, organogenic and argillaceous sediments. It is defined by three sedimentary cycles, and is characterized by five sedimentary facies (coalbearing facies, upper oil shale-bearing facies, upper mudstone facies, lower oil shale-bearing facies and lower mudstone facies). The lower mudstone and lower oil shale facies are classified as cycle one, whilst the upper mudstone and the upper oil shale are classified as cycle two. The coal-bearing facies is classified as cycle three. In Moye area the sedimentation is dominated by alternating heterolithic facies of sandstones, siltstones, mudstones, carbonaceous sediments and coal seams. Here, coal-bearing horizons are predominantly associated with sedimentary cycle one and two, and rarely with cycle three. The facies distribution in the lower sedimentary unit is shown in Figures 3, 6, 7 and 8.

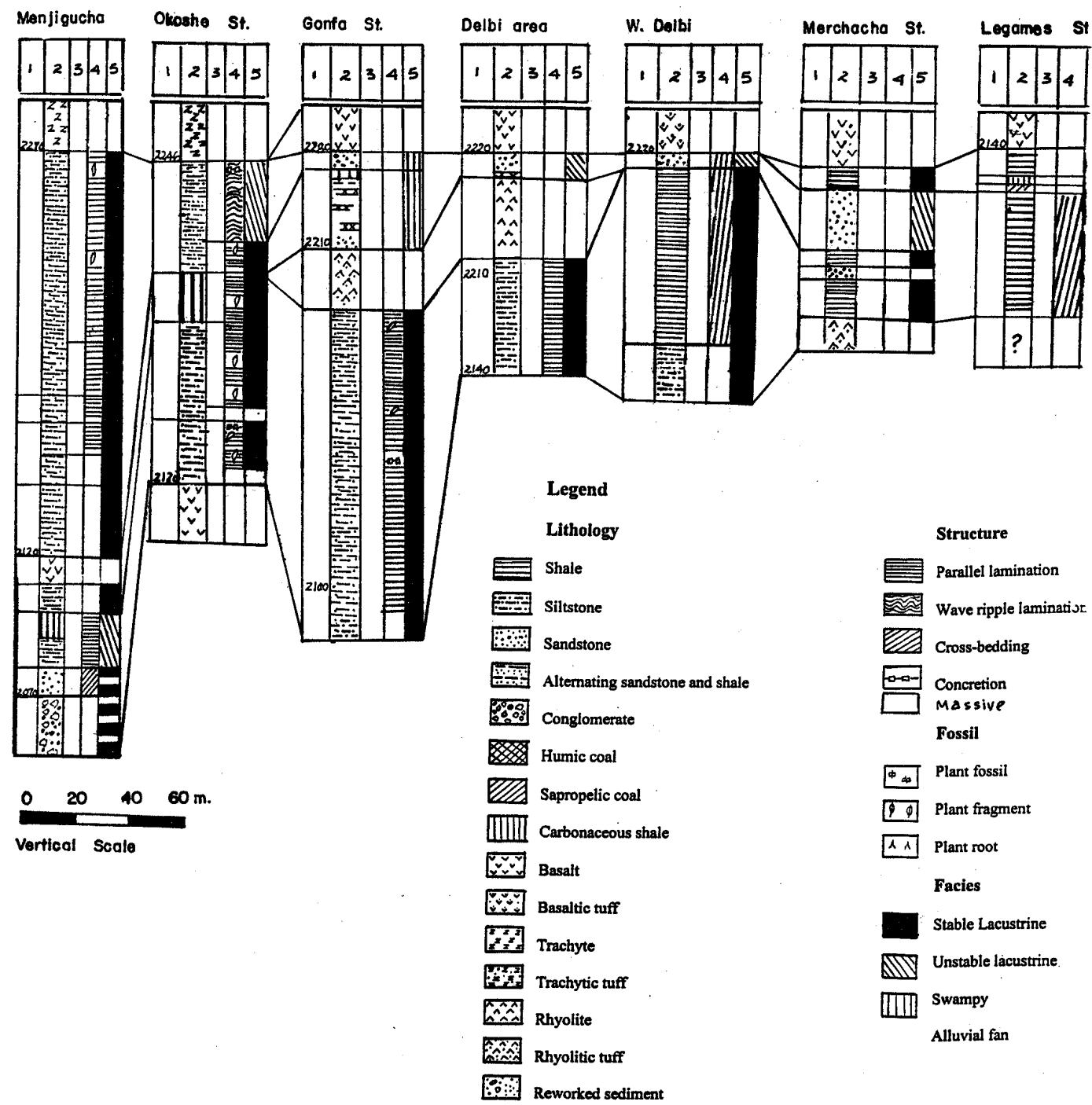

Fig. 5. Outcrop correlation sections of Delbi area. (1=Elevation, $2=$ Lithology, $3=$ Thickness in metre, $4=$ Sedimentary structures and fossil, 5=Facies). 
Lower mudstone, gravely sandstone and sandy conglomerates facies

This facies unconformably overlies the lower basaltic substratum of Ashanghe series. The marginal areas are dominated by sandy conglomerate and gravely sandstone facies. Poorly-sorted massive to crudely bedded sandy conglomerate is exposed and attains a thickness of 2-5 $\mathrm{m}$ at the basin margin. The sandy conglomerate consists of extraformational boulders and pebbles of basalt and intraformational mud clasts. The clast size ranges from 5 to $50 \mathrm{~cm}$ in diameter, with sub-rounded grain morphology.
The sandy conglomerate is the coarsest facies in the lower sedimentary unit.

The matrix-supported sandy conglomerate laterally changes to massive and to flat bedded gravely sandstone facies. The reddish brown poorly-sorted gravely sandstone is composed largely of coarse to medium-grained sand grains. The facies attains a thickness of $5-10 \mathrm{~m}$. Thin laminae and lenses and beds of shales and siltstones are interbedded within the unit. The gravely sandstone laterally passes into mudstone facies.

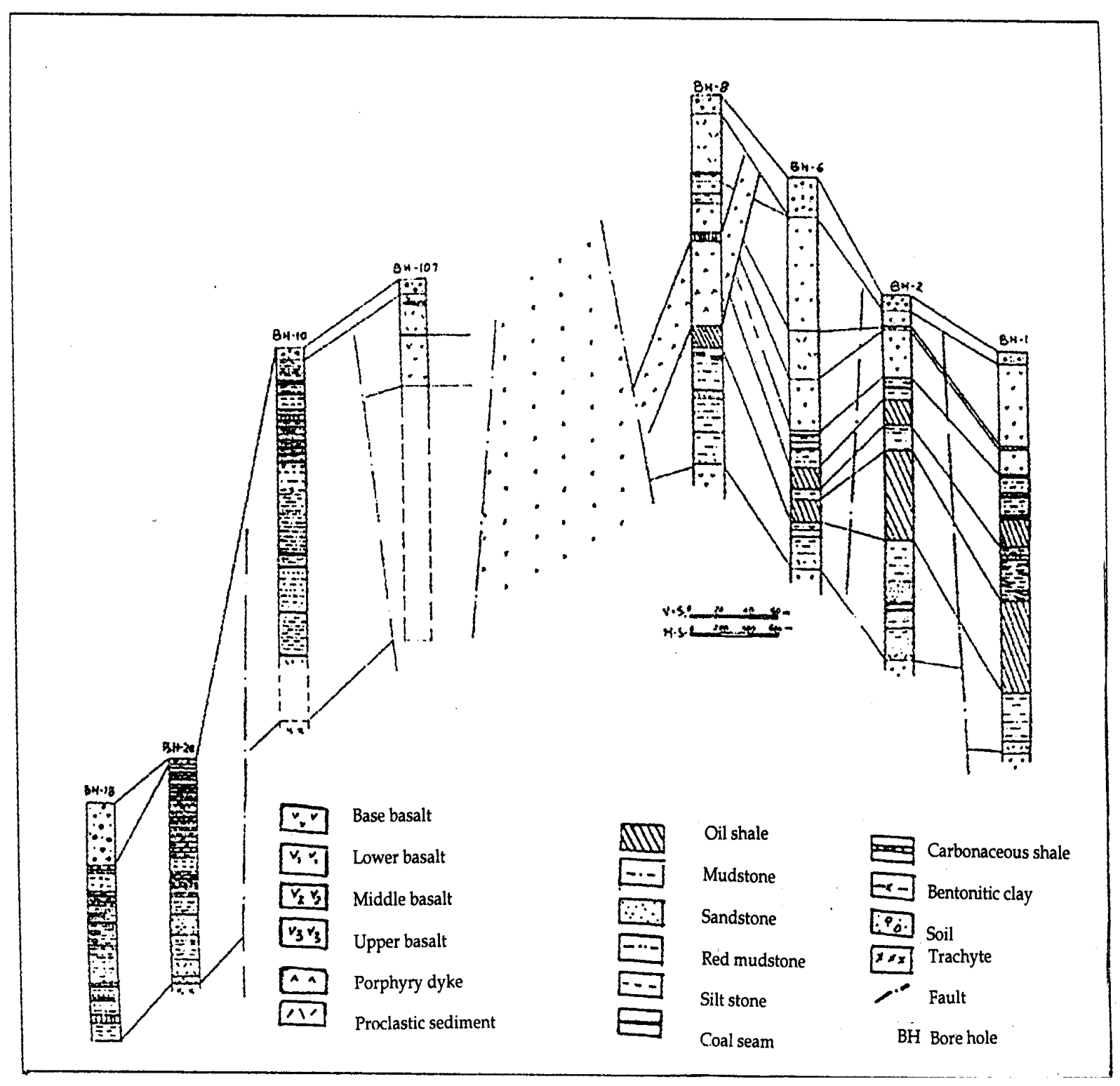

Fig. 6. Sub-surface correlation, Delbi-Moye Basin. 
The lower mudstone facies varies in thickness from 30-200 meters, and is composed mainly of fine-coarse clastics (very fine-grained sandstones, mudstones, siltstones and shales). Thin ash and bentonitic clay beds are intercalated at different levels within the sequence. In the uppermost part, coal seams (1-2 m thick) are inter-bedded with the lower mudstone facies in the western part of the basin (Moye area). Planar and trough cross-beds, flat beds, contorted beds, parallel lamination and cross- laminations, multiple scour and erosional surfaces, channel filling, desiccation cracks, circular and elongated sideritic concretions are the prominent sedimentary structures in the lower mudstone. The lower mudstone facies is well recognized in boreholes $\mathrm{BH}-1, \mathrm{BH}-2, \mathrm{BH}-6, \mathrm{BH}-8$ in the Delbi area, and in boreholes BH-107, BH-10, BH18, BH-19, BH-20 and BH-21 (Figure 6).

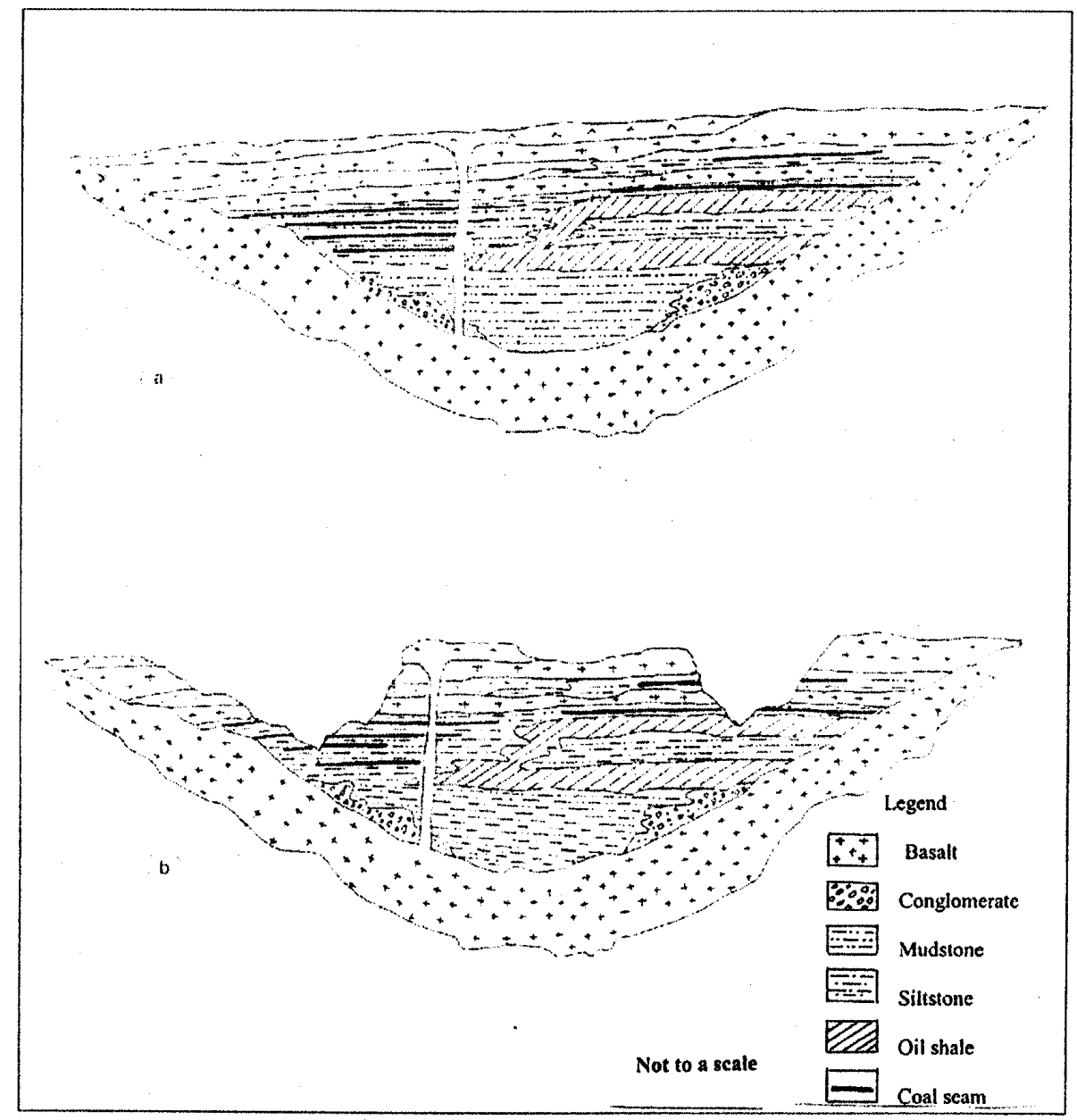

Fig. 7. Facies model of the Delbi-Moye Basin with faults omitted: (a) at the time of deposition and volcanic eruption, (b) present geomorphological setting.

\section{Lower oil shale facies}

The lower oil shale horizon is exposed in the stream channels of Legamse and Merchacha, and is characterized by brown to dark brown, fissile to massive sedimentary structures. The lower oil shale facies contains abundant leaf and fossil fragments. It attains a thickness of 60 meters in the central part of the basin and pinches out towards the western part of the basin (Moye area). Sideritic beds and concretions are interbedded within the facies. The facies shows horizontal to gentle dipping $\left(13^{\circ}-25^{\circ}\right)$ towards west. The oil yield decreases generally from top to bottom of the sequence, from east to west and from north to south within the basin. The lower oil shale facies is well recorded in borehole BH-1, 2, 6, 7, 8 and 11. The lower oil shale attains a maximum oil yield of $60 \mathrm{lit} / \mathrm{ton}$, but 30-40 lit/ton predominates. Lean shale beds are also interbedded within the lower oil shale facies. The distribution of lower oil shale facies is shown in Figures 4, 6, 7 and 8 . 

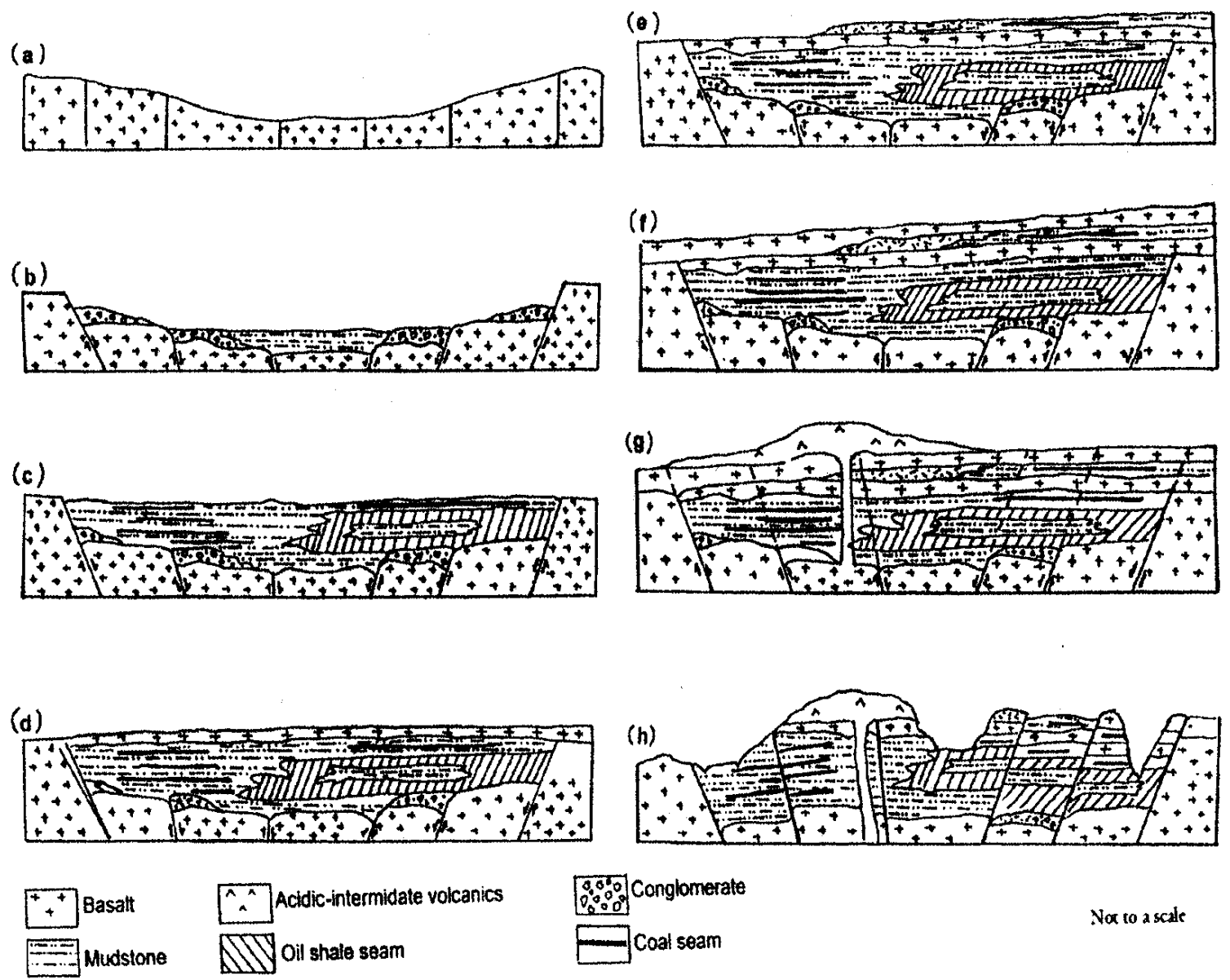

Nox to a scale

Fig. 8. Reconstruction of the Delbi-Moye Basin.

\section{Upper mudstone facies}

The upper mudstone facies range in thickness from 0 to $32 \mathrm{~m}$, attaining a maximum thickness in the eastern part of the basin (borehole BH-1, BH-2 and $\mathrm{BH}-7$ ), and pinching out towards the southern and western parts of the basin. The upper mudstone is characterized by dark grey to brownish grey, hard, blocky, loaded/scoured base, massive beds, flat-beds, planar cross-beds, contorted beds, concretion and plant fossils. Generally, trough cross-beds, planar cross-beds, planar lamination and horizontally stratified alternating heterolithic mudstones, siltstones dominate the sedimentation. Ash beds are also intercalated at different levels of the sedimentation.

In Delbi area, in borehole BH-1 the lower part of the upper mudstone is dominated by $24 \mathrm{~m}$ of alternating cross-bedded, flat bedded, massive and horizontally laminated mudstones. Thin beds and lenses of sandstones $0.1-2 \mathrm{~m}$ thick are intercalated at different levels of the sequence. The muddy facies passes upwards into a 3 meter thick massive

sandstone, and in turn, passes upwards into 5 meters thick horizontally laminated mudstones. The sandstone beds and lenses disappear and change into mudstone lithofacies in borehole BH-2. Planar cross-beds, flat beds and massive beds are the prominent sedimentary structures in borehole $\mathrm{BH}-2$. The upper mudstone facies distribution is shown in Figures 4, 6, 7\&8.

\section{Upper oil shale facies}

The oil shale seams are grey-olive grey to brown in colour. Grey-olive grey oil shales developed in the western part of the basin, whilst brownish fissile oil shale developed in the eastern part of Delbi. The upper oil shale attains a maximum thickness of 20 meters at the depocenter (Legamese Stream, borehole BH-1 and BH-2), and decreases to 10 meters in borehole $\mathrm{BH}-8$, and it is totally absent at the western extreme of the basin (Moye area). The oil shale seams change to finer clastic sediments (lean shale and mudstone) towards the 
western part of the basin. The facies exhibited welldeveloped fissility in the eastern part, but laterally, change to massive, flaggy to loose appearance in the western part of the basin. The fissile oil shale in the eastern part of the basin is characterized by high tar contents and elevated TOC value. Lipidrich planktonic algal and amorphous materials predominate. Extensive planktonic growth in shallow photic zones was accompanied by influx of land-derived organic material from the rift margins. Tuffaceous beds from the mild volcanic episodes developed at different levels within the upper oil shale facies. Sideritic concretions and beds are recorded at different levels of the sedimentation. The distribution of upper oil shale facies is shown in Figures 4, 6, 7\&8.

\section{Coal-bearing facies}

The coal-bearing facies is composed of alternating horizontally bedded, flat bedded and crosslaininated carbonaceous shales, carbonaceous mudstones, ash beds and coal seams. The coalbearing sediments and coal seams range in thickness from 15 to $278 \mathrm{~m}$ and from 0.1 to $2.2 \mathrm{~m}$, respectively. The coal seams are characterized by brownish to black, compacted to earthy appearance with conchoidal, massive and prismatic fractures. Generally, the coal seams are interbedded with grey mudstones, carbonaceous shales and ash beds. The coal seams in the Moye area are dominated by humic coal (vitrain, clarian and rarely fusian lithotypes), whilst the Delbi area is dominated by sapropelic coal (boghead and rarely cannel lithotypes). Boghead and minor amounts of oil shale seams are concentrated at the depocenter of the basins; whereas humic coal is concentrated at the marginal areas of the basin. The coal-bearing horizon attains visible thickness of 15 meters in the Legamse Stream, 10 meters in Yeba Stream, 9 meters in the Ramete Stream sections. The coal beds show horizontal to gentle dipping $10-13^{\circ}$ towards west. Sideritic concretions and beds are associated with the coal-bearing horizons. Thin beds and lenses of carbonaceous shales and mudstones are also interbedded with the coal seams.

In the Delbi area, along the north-south drilling prospection line, coal-bearing sediments are recorded in boreholes (North-BH-7-BH-1-BH-102-BH4-South). In boreholes BH-1 and BH-7, the coalbearing sediments overlie the upper oil shale facies, but laterally the thickness decreases towards borehole $\mathrm{BH}-101 \mathrm{~B}$ and $\mathrm{BH}-4$. The coal-bearing sediments attain a thickness of 25 meters in borehole BH-1 and 61 meters in BH-7. Sapropelic coal seams ranging in thickness from 0.2 to $1.8 \mathrm{~m}$ with a composite thickness of $6.7 \mathrm{~m}$ are interbedded with coal-bearing sediments in borehole BH- 1 (see Figures 7 and 8 ); 0.5 to $1 \mathrm{~m}$ thick coal seams are inter-bedded with the coal-bearing sediments in boreholes BH-7, BH-4 and BH-101B.

Coal-bearing sediments are also recorded along the east-west drilling prospection line (East-BH-1BH-2-BH-6-BH-BH-6-107-BH-10-BH-19-BH-21-West).

The number of sapropelic coal seams decreases from the central part towards the western part of the basin. In the western part, the coal seams are dominated by humic coal lithotype, possibly derived from influx of land-derived materials from the rift margins. Three coal seams with a composite thickness of $5.3 \mathrm{~m}$ are interbedded with the coalbearing sediments in borehole $\mathrm{BH}-2$. In borehole BH-6, three sapropelic coal seams $(0.5-1.1 \mathrm{~m})$ are interbedded with $15 \mathrm{~m}$ thick coal-bearing sediments. Towards the western part of the basin, in borehole BH-107, the sapropelic coal seams disappear, and interfinger with dark grey mudstone facies.

In Moye area, in borehole BH-19, sedimentary cycle one consists of four humic coal seams ranging in thickness from 0.7 to $1.2 \mathrm{~m}$. In sedimentary cycle two, four humic coal seams range from 0.7 to $1.05 \mathrm{~m}$ thick are interbedded with coal-bearing sediments at different levels of the sedimentation. In borehole BH-21, in sedimentary cycle one, five humic coal seams ranging from 0.2 to $1.5 \mathrm{~m}$ thick are interbedded with the coal-bearing sediments. For the distribution of coal-bearing sediments see Figures 4, 6, 7 and 8.

X-ray diffraction and scanning electron microscope (SEM) studies indicated the presence of authigenic minerals pyrite, calcite, quartz, smectite, $\mathrm{K}$-feldspar and rarely kaolinite and chlorite in the lacustrine sediments.

\section{Upper sedimentary unit}

The upper sedimentary unit is found between the middle basalt and the upper basalt units. The sediment is composed mainly of reworked pyroclastic deposits (tuffaceous breccia, tuffaceous sandstones, tuffaceous siltstones and tuffaceous mudstones), and carbonaceous sediments (coal seams and carbonaceous shale). This sedimentary unit is encountered in boreholes $\mathrm{BH}-1, \mathrm{BH}-2$, BH-6, BH-8 and it pinches out towards the western extreme part of the basin (Moye area). The unit attains a maximum thickness of 40 meters in borehole BH-6. The sedimentation shows upward- 
fining trend, and it is characterized by massive beds, cross-beds, flat beds, cross-lamination and horizontal lamination. The coal seam is interbedded with the coal-bearing sediments. A 2meters thick humic coal seam is inter-bedded with the coal-bearing sediments in borehole $\mathrm{BH}-1$, but laterally after 500 meters in borehole $\mathrm{BH}-2$ the changes to carbonaceous and pyroclastic sediments. For facies distribution of the upper sedimentary formation see Figures 6, 7 and 8 .

\section{SEDIMENTOLOGICAL AND DEPOSITIONAL ENVIRONMENTS INTERPRETATION}

Planar cross-beds, trough cross-beds, flat beds, massive beds, convolute beds, horizontal lamination and cross-lamination, multiple scours and erosional surfaces, channel filling and desiccation cracks are the sedimentary structures in the Delbi-Moye Basin. Of these, the flat beds, massive beds, parallel lamination, cross lamination account for about $80 \%$ and cross-beds, contorted beds, sideritic beds and concretions account for $20 \%$. Planar cross-beds with a tangential relation to the lower surfaces predominate over trough crossbeds.

Sandy conglomerate and gravely sandstone suggest high-energy environment sedimentation, whilst claystones, shales, mudstones and siltstones suggest low-energy sedimentation. In general, the sedimentation appear to be characterized by alluvial fan, fluviatile, off shore lacustrine, shore line lacustrine, swampy and/or paludal depositional environments.

\section{Alluvial sedimentation}

The patchy, poorly sorted, massive to crudely bedded sandy conglomerates and gravelly sandstones are interpreted as alluvial fan sedimentation. The NNW-SSE trending extensional faults favoured the accumulation of alluvial fan sedimentation. The contrast in topography and intermittent stream action and sudden change in slope are characteristic features of alluvial sedimentation (Allen, 1965; Bull, 1972). The sandy conglomerates and gravelly sandstones indicate proximal to mid fan deposits, and are interpreted as river and debris-flow sedimentation.

Textural immaturity and lack of sedimentary structures are typical features of alluvial fan sedimentation. Compositional similarity of the pebble in the conglomeratic facies reflects basaltic source area geology. Generally, fans are developed along the fault line scarps. However, case studies show that a fan can be developed at the unfaulted basin margins (Lorenz, 1988; Wolela Ahmed, 1997).

The upward fining sequence reflects fan retreat due to scarp recession and/or source area planation during tectonically quite periods (Elliot, 1983). The inter-bedded shales and siltstones are interpreted as being finer sediments that settle out of suspension after sheet flooding and/or the disintegration of finer sediments and mechanical infiltration through the conglomerate. The reddish to reddish brown colour is characteristic of most alluvial fan deposits of semi-arid areas, reflecting sub-aerial conditions.

\section{Fluviatile sedimentation}

Changes in sedimentary structures through planar cross-beds, trough cross-beds, flat beds, massive beds and calcrete palaeosol horizons suggest fluviatile sedimentation. Lateral changes in grain size, bedset geometry and sedimentary structures across individual beds are common. Variation in sedimentary textures and structures along the strike within individual bedsets reflect the distribution of grain size and bedforms (Willis, 1993). The deposition of coarser and finer sediments reflects the transition from active rifting to passive subsidence. The fining upward from sandy conglomerates to sandstones are inconsistent with fluviatile sedimentation. However, the bed-load dominated coarse-grained sedimentation passes vertically up into finegrained suspension-load dominated flood-plain sediments indicating change in the source area relief (tectonic) and/or changes in climate (Steel, 1974; Ramos, 1995).

The sedimentation shows well-developed cyclicity with a fining upward trend and is dominated by suspension-load sediments indicating a meandering river deposition. A high suspension-load/bed-load ratio indicates sedimentation by over-bank flooding. Mudstone and siltstones-dominated flood-plain assemblage is interpreted as a meandering river deposit on the basis of over-bank sedimentation. The sharp erosional surfaces indicate frequent fluctuation in the water level in the river channel, resulting in periodic seasonal emergence and subsequent erosion of channel bars (Singh and Bhardwaj, 1991). The channel lag deposits, flat beds, massive beds and parallel laminated heterolithic facies indicate a high-flow regime sedimentation; whilst planar cross-beds and trough cross beds belong to low-flow regime sedimentation (Harms et al., 1963; Belal et al., 1994). The flat bedded sandstones and siltstones indicate high-flow regime sedimentation during flood stage. Sandy conglomerates and 
horizontally stratified coarse-grained sandstones in the lower part of the sedimenation also indicate planar sheet deposition under a high-flow regime (Casshyap and Kumar, 1987). The passage from cross-bedded mudstones to massive sandstones indicate a change in the velocity of flow from lowflow regime to high-flow regimes, whilst the passage from horizontally bedded mudstones to cross-bedded mudstones indicates a change from high-flow regime to low-flow regime.

The alternating heterolithic thinly laminated siltstones, mudstones and very fine-grained sandstones represent a sheet flood succession formed under decelerating flood flows, indicating upper-flow regime. The fine-grained horizontally laminated sandstones, siltstones and mudstones have resulted from suspension-dominated waning floods (Singh and Bhardwaj, 1991). Discontinuous sandstone lenses encountered in mudstones are formed under short-lived pulses of high-energy conditions, whilst the presence of shale lenses and laminae in sandstones indicate high-energy environment interrupted by low-energy environment (Hassan, 1998).

The sideritic concretions and beds within the sedimentation are typical of semi-arid environment. In semi-arid to arid climate where there is excess evaporation over precipitation, soluble salts are concentrated in the upper layer to produce carbonate concretions (Suttner and Dutta, 1986; Wolela Ahmed, 1991a; 1997). The presence of concretions and/or nodules in the uppermost part of succession indicates palaeosol features in the flood-plain. Concretions and beds of carbonate reflect the localized precipitation of cement from the pore water within the sediments. Pedogenic calcrete horizons are formed during extended periods of landscape stability with no fluviatile sedimentation (Allen, 1974; Kraus and Middleton, 1987).

\section{Lacustrine sedimentation}

The lacustrine deposits in the Delbi-Moye Basin reflect lacustrine deposition in a tectonic basin.. This lacustrine sedimentation is characterized by fresh water, deep, both oxygenated and anoxic depositional environments. The sedimentation exhibited a combination of clastic, organogenic and chemical sediments. Combination of these end member are common in ancient lacustrine deposits (Lorenz, 1988; Shahin, 1993; Wolela Ahmed, 1997). Coarse siliciclastic sediments best develop in hydrologically open lakes, whilst hydrologically closed lakes tend to be sites of evaporite and limestone deposition (Tucker, 1991; GierlowskiKordesch and Huber, 1995; Wolela Ahmed, 1997).
Several studies have shown that thick lacustrine sequences develop near the faulted rift margins (Hubert et al., 1992; Gierlowski-Kordesch and Huber, 1995; Wolela Ahmed, 1997). Faults may act as barriers to river flows either as a constraint on lateral migration or by damming the flow water to form lakes (Alexander and Leeder, 1987). The depocenter of the lacustrine deposits is dominated by fine-grained sediments (siltstones, mudstones, carbonaceous shales, coal seams and oil shale seams), whilst the marginal areas are dominated by coarse-grained sediments (sandy conglomerates and sandstones). The lacustrine sedimentation in the Delbi-Moye Basin is characterized by off shore and shore line sedimentation.

\section{Off shore lacustrine sedimentation}

The off shore lacustrine deposits concentrated at the depocenter of the Delbi-Moye Basin indicating stable lacustrine depositional environment. The sedimentation is dominated by fine-grained siliciclastic and organogenic deposits, and accompanied by volcanogenic sediments. The intercalation of ash beds within the lacustrine sedimentation reflects contemporaneous volcanic episodes. Thick sequences of brown black-black oil shale seams, dark brown to black sapropelic coal, and minor amounts of humic coal indicate deep euxinic depositional environments. Black mudstones are also an indicator of deep lacustrine depositional environments (Hubert et al., 1976; Bae et al., 1989; Wolela Ahmed, 1991a). The brownish oil shales reflect abundant organic content during sedimentation. The laminated black mudstones, oil shale and sapropelic coal deposits and landderived clastic detritus indicate that the sedimentation was enriched by material derived from the faulted rift margins. The presence of thick oil shale seams and sapropelic coal indictate extensive planktonic algae growth within a shallow photic zone. The presence of type-I and II kerogen reflect that the presence of high content of algal and amorphous materials at the time of sedimentation. The oil shales yield high liquid hydrocarbon, reflecting the presence of high lipitine contents. The intercalation of sapropelic and humic coals indicate allogenic and autogenic character of the sedimentation. The presence of Botryococcus and Pediastrum indicate lacustrine depositional environment, possibly brackish water conditions.

The thinly fissile lamination (varves) is an indicator of a lacustrine environment. The presence of sideritic concretion and beds are indicators of subaerial exposures during a lacustrine regression. The oil shale in the eastern block in Delbi area is 
characterized by well developed fissility and indicates a slow-rate of sedimentation; whilst the flaggy-massive appearance in the western part of the basin indicates a rapid-rate of sedimentation. The lower abundance of leaf fossils in the eastern Delbi is inconsistent with its higher maturity; whilst the western block of Delbi is dominated by leaf fossils, reflecting low maturity. The interfingering of mudstones and oil shale seams reflect facies variations within the sedimentation. Palynological studies indicate the presence of species of algae (Botroyoccus and Pediastrum), angiosperm pollen, fern spores and fungal spores (see Table 2). The assemblage of identified species suggests that the relative age of the oil shale deposit in the Delbi-Moye Basin is Eocene-Miocene (Table 2). The palynomorph association in the Delbi-Moye Basin also indicates lacustrine depositional palaeoenvironment. The presence of bentonitic clay indicate the alteration of volcanic ash and/or basic volcanics.

Electron microscopy studies of the Delbi oil shale indicated that it predominantly consists of clay minerals (smectite and minor amounts of kaolinite and chlorite), crystals of pyrite, quartz and feldspar. The presence of pyrite, organic matter and siderite concretions and beds are also indicators of lacustrine environment.

Table 2. Palynomorph taxa results of the Delbi-Moye Basin.

\begin{tabular}{|c|c|c|c|}
\hline Shigute Gelta (1988) & $\begin{array}{l}\text { AMOCO Production Com- } \\
\text { pany (1988) }\end{array}$ & $\begin{array}{l}\text { Crude Oil Research Institute of } \\
\text { Korea (1988) }\end{array}$ & This study \\
\hline Palynomorph taxa & Palynomorph taxa & Polypodiacea sporites haardti & Botryococcus \\
\hline Polypodiidites & Ctenosporites & Polypodiacea usmensis & Pediastrum \\
\hline Faveosporites & Dicellae sporites & Polypodiacea adiscordatus & Tricolpites sp (fungal spore) \\
\hline Polipodiisporities sp. & Diporicellae sporites & Cyathiditas minor & Polpodii sporites favus \\
\hline Cathiditees & Monocellate & Osmudacidites wellmanii & \\
\hline Tetracellates sp. & Pentacellate & Schizaeoi sporites & Polypoiaceaisprite sp. \\
\hline Pluricellae sporites sp. & Perithecites & Inapertupollenites & Polypodii sporite sp. \\
\hline Diporicellae sporites & Tetracellates & Ephedripites sp. & Tetracolporopollenites sp. \\
\hline Tricolorate triporate & Tricellate diaperturate & Monosulcites Minimus & Faveosporites sp. \\
\hline Arecipites & Cingulate sporites sp. & Quercoidites sp. & Polypodiacea sporites haardti \\
\hline Monoporate sp. & Cyathidites & Magnolipollis sp. & Extrapuncato sporites sp. \\
\hline Botryococcus & Cavigato sporites & Tricoloporo pollenites & Monosulcites minimus \\
\hline Pediastrum & Monolete spinate & Tripollnites liblaresis & Inaperturo pollenites sp. \\
\hline \multirow{15}{*}{$\begin{array}{l}\text { Relative age: Oligocene- } \\
\text { Miocene }\end{array}$} & Polypodiidites & Convolvulaceae & Taxodiacae pollenites hiatus \\
\hline & Polypodii sporites & Myrataceidites & Tricol pollenites liblarensis \\
\hline & Temesipters sp. & Araceae & \multirow{12}{*}{ Relative age: Eocene(?)-Miocene } \\
\hline & Trilete faveolate & Jendufouria seanorogiforms & \\
\hline & Verrumonoletes & Pterisisporites sp. & \\
\hline & $\begin{array}{l}\text { Fenestrites sp. } \\
\text { Monoporate microgranu- } \\
\text { late }\end{array}$ & $\begin{array}{l}\text { Extrapuncato sporites sp. } \\
\text { Gleichniidtes } s p \text {. }\end{array}$ & \\
\hline & Retitricol scabrate & Lophotriletes sp. & \\
\hline & Tricolporate reticulates & Stenozonotriletes sp. & \\
\hline & & Deitoidospora sp. & \\
\hline & Tricolporate scabrate & Inapertupollenites sp. & \\
\hline & \multirow{5}{*}{$\begin{array}{l}\text { Relative age: Oligocene- } \\
\text { Miocene }\end{array}$} & Taxodiacae pollenites hiatus & \\
\hline & & Psophosphaera sp. & \\
\hline & & Araucariacidites sp. & \\
\hline & & $\begin{array}{l}\text { Cioadopites sp. } \\
\text { Jussitriporites sp. }\end{array}$ & \\
\hline & & Relative age- lower limit Eocene & \\
\hline
\end{tabular}




\section{Shore line sedimentation}

The marginal area sedimentation of sandstones and siltstones indicate unstable lacustrine sedimentation. Fluctuation in water level can produce extensive shoreline deposits (Picard and High, 1972). Most lakes are dominated by regression-dominated history. This lithological association perhaps indicates intersection of fluviatile system with the lake margins. The presence of coarser bed-load materials, possibly indicate Gilbert delta sedimentation (Lorenz, 1988; Tucker, 1991). Rift valley lakes have considerable shallow water environments, which are good sites for the deposition of sandstones, siltstones, mudstones and some carbonates (Hubert et al, 1976; Geirlowski-Kordesch and Huber, 1995: Wolela Ahmed, 1997). The presence of calcrete within the lacustrine deposits is an indicator of subaerial exposure of sequences.

\section{Swampy or paludal sedimentation}

The coal seams are rhythmically interbedded within the carbonaceous sediments, and are traceable for hundreds of meters. The coal-bearing sediments in the western Delbi and moye areas perhaps reflect paludal and/or swampy depositional environment. The flood-plains contain swamps usually covered with dense vegetation in the humid tropical climates, which may develop into coal seams (Wolela Ahmed, 1991a). The influx of land-derived plant materials also contributes for the development of coal seams in the swampy areas in the flood plain.

\section{BASIN EVOLUTION}

Alluvial fan, fluviatile and lacustrine-dominated sedimentation in the Delbi-Moye Basin underwent various tectonic disturbances, and the distribution of the sedimentation is explained in relation to the post-sedimentation tectonics. The following basin evolution is envisaged to have taken place in the Delbi-Moye Basin:

(i) Deep-seated linear fractures in Early Tertiary activated the emplacement of voluminous lava, which levelled the pre-existing uneven morphology. The sedimentation took place on a basaltic substratum of the Ashangi Trap series. A NNWSSE trending extensional fault system created narrow grabens and half-grabens for the sedimentation in the Delbi-Moye Basin (Fig. 8a).

(ii) Alluvial fan, fluviatile and lacustrine dominated the lower sedimentary unit unconformably overlies on the lower basalt. The unit mainly consists of the lower mudstone, lower oil shale, upper mudstone, upper oil shale and coal-bearing facies (Figs $8 b$ and c).

(iii) The deposition of the lower sedimentary unit in the Delbi-Moye Basin was interrupted by volcanic activity (Fig. 8d). The lower sedimentary unit is overlaid with the middle basalt (basalt-II).

(iv) The middle basalt is overlaid with the upper sedimentary unit. Fluviatile and swampy faciesdominated the upper sedimentary unit, which consists of tuffaceous sandstones, tuffaceous siltstones, tuffaceous mudstones, carbonaceous clay and coal seams (Fig. 8e).

(v) The upper sedimentary unit is overlaid with upper basalt (basalt-III). The upper basalt, in turn, is overlaid with acidic-intermediate volcanic rocks (rhyolite, trachyte and rarely andesite) (Fig. 8g).

(vi) After volcanism and sedimentation the NNWSSE trending fault system reactivated and dissected the whole volcanic and sedimentary rocks. In the Late Tertiary, the volcanic rocks and the sedimentary formations were dissected by young ENE-WSW fault system. This fault system is inconsistent with the East African Rift system. The present distribution of the rock types is explained in relation to the NNW-SSE and ENEWSW tectonic features. The ENE-WSW trending fault system controls the presenct distribution of the coal and oil shale-bearing basins in the study area. Most of the sediments on the upthrown blocks were removed by erosional activity, and the sediments on the downthrown blocks are preserved (Fig. 8h).

\section{SUMMARY AND CONCLUSIONS}

Surface and sub-surface drilling results help to understand the sedimentological aspect of the basin (lateral and vertical facies variation in lithology and sedimentary structures). The sedimentation in the Delbi-Moye Basin took place in $8 \mathrm{~km}$ asymmetrical graben formed by a nearly NNW-SSE trending extensional fault system. In the late stage, the NNW-SSE trending fault system rejuvenated and dissected the whole volcanosedimentary succession.

The marginal faults favoured the accumulation of alluvial fan sandy conglomerates and sandstones. The alluvial fan deposits are characterized by proximate-mid fan sedimentation, reflecting river and debris flow-dominated sedimentation. 
Well-developed cyclicity, fining up trend, high suspension-load/bed-load ratio and palaeosol features indicate a meandering river sedimentation. The channel lag deposits, flat beds, massive beds and parallel laminated heterolithic facies indicate a high-flow regime sedimentation; whilst planar cross-beds and trough cross-beds reflect low-flow regime sedimentation. The presence of sideritic beds and concretions within the sedimentation are considered palaeosol features in the flood plain.

The lacustrine sedimentation in the Delbi-Moye Basin is characterized by off shore lacustrine at the depocenter and shoreline lacustrine deposition at the marginal areas of the basin. The depocenter of the lacustrine sedimentation is dominated by finegrained clastic and organogenic sediments; whereas the marginal area of the basin are dominated by coarser-clastic sediments. The concentration of olive grey-black oil shale facies and brown-black sapropelic coal seams high at the central part of the basin, indicating euxinic depositional environment. The oil shale in the eastern block in Delbi area is characterized by well developed fissility and indicates slow-rate sedimentation; whilst the massive and flaggy-loose appearance indicates rapid-rate sedimentation. The humic coal-bearing sedimentation in the Moye area probably is related to lacustrine and/or paludal or swampy depositional environments.

\section{ACKNOWLEDGEMENTS}

Earlier drafts of the manuscript were read by Mr. G. J. Bae and Assefa Aklilu. Their constructive and valuable comments are gratefully acknowledged. Thanks are also extended to Dr. Gazahegn Yirgu and the anonymous referees of SINET for their constructive and valuable comments of the manuscript. The manuscript has also substantially benefited from comments and helpful discussions of colleagues at Coal and Oil Shale Exploration Section, Geological Survey of Ethiopia. Finally, I would like to thank Ketsela Tadesse for processing the data by computer.

\section{REFERENCES}

1. Allen, J.R.L. (1965). A review of origin and characteristics of recent alluvial sediments. Sedimentology 5:89-191.

2. Allen, J.R.L. (1974). Studies in fluviatile sedimentation: implication of pedogenic carbonate units, Lower Old Red Sandstone, Anglo-Welsh outcrop. Geological Journal 9:181-208.

3. Alexander, J. and Leeder, M.R. (1987). Active tectonic control on alluvial architecture. In: Recent Development in Fluvial Sedimentology. Vol. 76, pp. 99-109, (Ethridge, F.G., Flores, R.M. and Har- vey M.D., eds). Soc. Econ. Paleon. Mineral. Spec. Pub.

4. Assefa Aklilu, Minye Betru, Wolela Ahmed, Getahun Belay and Asmamaw Temesgen (1987). Geological report on coal occurrences of MetesoSoyoma areas. A report, Ministry of Mines and Energy, Addis Ababa.

5. AMOCO Production Company (1988). Palynological Analysis of Oil Shale Samples from Ethiopia. Tulsa, Oklahoma, USA.

6. Bae, G.Y., Minye Betru, Getahun Belay, Wolela Ahmed, Yirga Tura and Asmamaw Temesgen (1989). Report on the geology and sub-surface exploration for coal and oil shale deposit of the Delbi and surrounding areas, Keffa Administrative Region. A report, Ministry of Mines and Energy, Addis Ababa.

7. Bae, G.Y., Wolela Ahmed and Yirga Tura (1991). Report on the geology, sub-surface exploration, reserve estimation and geochemical characteristics of coal and oil shale deposits of the DelbiMoye Basin. A report, Coal Division, Ministry of Mines and Energy, Addis Ababa.

8. Belal, S.A. Werner, S. and Abdulkader, M. A. (1994). Evolving fluvial-transitional-marine deposition through the Cambrian sequence of Jordan. Sedimentary Geology 89:65-90.

9. Bull, W.B. (1972). Recognition of alluvial fan deposits in the stratigraphic record. In: Recognition of Alluvial Sedimentary Environment. Vol. 16, pp. 6883, (Rigby, K.J. and Hamblin, W.K., eds). Soc. Econ. Paleon. Mineral Spec. Pub.

10. Casshyap, S.M. and Kumar, A. (1987). Fluvial architecture of the Upper Permian Raniganj Coal Measures in the Damodar Basin, eastern India. Sedimentary Geology 51:181-213.

11. Crude Oil Research Institute of Korea (1988). Results on preliminary analysis of oil shale and coal sample, (unpublished report).

12. Ebinger, C.J., Tesfaye Yemane, Giday Wolde Gabirel, and Aronson, J. (1993). Late Eocene-Recent volcanism and faulting in the Southern Main Ethiopian Rift system. Jour. Geol. Soc. London 150:99-108.

13. Ebinger, C.J. and Ibrahim, A. (1994). Multiple episodes of rifting in Central and East Africa: A reevaluation of gravity data. Geol. Rund. 83:689702.

14. Elliot, T. (1983). Facies sequences and sand-bodies of principal clastic depositional environments. In: Sediment Diagenesi, Vol. 115, pp. 1-56, (Parker, A. and Sellwood, B.W., eds). Reidel Publishing Company, Dordrecht, Holland.

15. Getahun Belay, Yirga Tura and Minye Betru (1993). Detail geological mapping, sub-surface exploration, geochemical studies and reserve evaluation of coal and oil shale resources at DelbiMoye Basin. A report, Ministry of Mines and Energy, Addis Ababa, 119 pp.

16. Gierlowski-Kordesch, E. and Huber, P. (1995). Lake Sequences in the Central Hartford Basin: Newark Supergroup. Guidebook No. 7: B1-B39. State Geological and Natural History Survey of Connecticut, USA. 
17. Harms, J.C., McKenzie, D.B. and McCabbin, D.G. (1963). Stratification modern sands of Red River, Louisiana. Jour. Geol. 71:566-590.

18. Hassan, M. (1998). Reservoir Management, Vol.I, pp. 5-6. Ministry of Mines and Energy, Addis Ababa.

19. Heeman, W., Belachew Tezera, Bisrat Yibas and Minye Betru (1984). Occurrences of coal and carbonaceous shale in Kefa, Gamo Gofa and Sidamo. A report, Ministry of Mines and Energy, Addis Ababa.

20. Hubert, J.F., Reed, A.A. and Carey, P.J. (1976). Paleogeography of East Berlin Formation, Newark Group, Connecticut Valley. Am. Jour. Sci. 276:1183-1207.

21. Hubert, J.F., Feshbach-Meriney, P.F. and Smith, M.A. (1992). The Triassic-Jurassic Hartford Rift Basin, Connecticut and Massachusetts: evolution, sandstone diagenesis, and hydrocarbon history. Am. Assoc. Petrol Geol. Bull. 76:1710-1734.

22. Kazmin, V. (1972). Geological Map of Ethiopia. 1:2,000,000. Published by Ethiopian Geological Surveys, Addis Ababa.

23. Kazmin, V. (1975). Explanation of geological map of Ethiopia. Geological Survey of Ethiopia Bulletin 1:1-15.

24. Kraus, M.J. and Middleton, L. (1987). Contrasting architecture of two alluvial suites in different structural setting. In: Recent Development in Fluvial Sedimentolog, Vol. 39, pp. 253-262, (Ethridge, F.G., Flores, R.M. and Harvey, M. D., eds). Soc. Econ. Paleon. Mineral. Spec. Pub.

25. Lorenz, J. C. (1988). Triassic-Jurassic Rift-basin Sedimentology: History and Methods. Van Nostard Reinhold, New York, 315 pp.

26. Mengesha Tefera, Tadious Chernet and Workineh Haro (1996). Explanation of the Geological Map of Ethiopia. Scale 1: 2000,000, Ethiopian Institute of Geological Surveys Bull. No 3:1-79.

27. Minye Betru, Wolela Ahmed and Asmamaw Temesgen (1987). Progress-technical report on the geology and coal occurrences of Meteso-DelbiMoye areas. Coal Division, Ministry of Mines and Energy, Addis Abeba. 8 pp.

28. Minye Betru, Wolela Ahmed and Asmamaw Temesgen (1988). Geological report on coal and oil shale indication in Delbi. A report, Ministry of Mines and Energy, Addis Ababa, 40 pp.

29. Picard, M.D. and High, L.R. (1972). Criteria for recognising lacustrine rocks. In: Recognition of Ancient Sedimentary Environments. Vol. 16, pp. 108-143, (Rigby, J.K. and Hamblin, W.K., eds). Soc. Econ. Paleont. Mineral. Spec. Pub.

30. Ramos, A. (1995). Transition from alluvial to coastal deposits (Permian-Triassic) on Island of Mollorca, western Mediterranean. Geol. Mag. 132:435-447.

31. Seife Michael Berhe, Belay Desta, Nicoletti, M. and Mengesha Teferra (1987). Geology, geochronology and geodynamic implication of Cenozoic magmatic province in $\mathrm{W}$ and SE Ethiopia. Jour. Geol. Soc. London 144:213-226.

32. Shahin, N. (1993). Petroleum Exploration and Geology. International Human Resource Development Corporation, Dire Dawa, Ethiopia. 300 pp.
33. Shigute Geleta (1988). Preliminary report on lignite exploration of Delbi area. A report, Ministry of Mines and Energy, Addis Ababa, 28 pp.

34. Singh, A. and Bhardwaj, B.D. (1991). Fluvial facies model of Ganga River sediments, India. Sed. Geol. 72:135-146.

35. Steel, R.J. (1974). New red Sandstone flood-plain and pediment sedimentation in the Hebridean Province, Scotland. Sedimentary Geology 44:336357.

36. Suttner, L.J. and Dutta, P.K. (1986). Alluvial sandstone composition and palaeoclimate: I. Framework Mineralogy. Jour. Sed. Petrology 56:329-345.

37. Tessfaye Lemma, Wolela Ahmed and Cheru Gelan (1992). Chemical analyses and characterisation of some Ethiopian coals. Bull. Chem. Soc. Ethiopia 6:59-73.

38. Tessfaye Lemma and Minye Betru (1995). Geochemical characteristics of Delbi oil shale. Bull. Chem. Soc. Ethiopia 9:79-91.

39. Tucker, M. (1991). Sedimentary Petrology: an Introduction to the Origin of Sedimentary Rocks. Second edition, Blackwell Science Ltd., 260 pp.

40. Willis, B. (1993). Ancient river systems in the Himalayan foredeep Chinii Village area, northern Pakistan. Sedimentary Geology 88:1-76.

41. Wolela Ahmed (1991a). Coal and Oil Shale Occurrences and their Geological Setting in Ethiopia. Volume I\&II, Ministry of Mines and Energy, Addis Ababa. 205 pp.

42. Wolela Ahmed (1991b). Highlights on coal and oil shale occurrences of Ethiopia (catalogue). A report, Ethiopian Institute of Geological Surveys, Note No 363, Addis Ababa.

43. Wolela Ahmed (1992a). An overview on the geographical distribution, geological setting and chemical characteristics of Ethiopian coal and oil shale. A report, Ethiopian Institute of Geological Surveys, Note No 364, Addis Ababa.

44. Wolela Ahmed (1992b). Significant coal deposits and their economic and mining possibilities in Ethiopia. A report, Ethiopian Institute of Geological Surveys, Note No 365, Addis Abeba.

45. Wolela Ahmed (1995). An overview of the geographical distribution, geological setting and chemical characteristics of Ethiopian coals. In: Proceedings of the Second Ethiopian Geosciences and Mineral Engineering Congress. August 7-9, 1992, pp. 29-47, (Tilahun Mamo, Solomon Tadesse and Metasebia Demessie, eds). SINET, Ethio. J. Sci., Vol. 18 (sup.), AAU Printing Press, Addis Ababa.

46. Wolela Ahmed (1997). Sedimentology, diagenesis and hydrocarbon potential of sandstones in hydrocarbon prospective Mesozoic rift basins (Ethiopia, UK and USA). PhD thesis, the Queen's University of Belfast, UK. 238 pp.

47. Zanettin, B. and Justin-Visentin, E. (1974). The volcanic succession in Central Ethiopia, the volcanism of western Afar and Ethiopian Rift margin. Memorie del Instituto di Geologia e Mineraloga dell Universita di Padova, Vol. 31, pp. 1-19. 